\title{
Crop Response to Soil Acidity Factors in Ultisols and Oxisols in Puerto Rico V. Sweet Potato $^{1,2}$
}

\author{
Fernando Abruña, José Vicente-Chandler, José Rodríguez, \\ José Badillo, and Servando Silva ${ }^{3}$
}

\begin{abstract}
The effect of various soil acidity factors on yield and foliar composition of sweet potato (Ipomoea batatas (L). Lam) were determined in three Ultisols and one Oxisol. Sweet potatoes responded moderately in yield to variations in soil acidity factors of three Ultisols, but did not on the Oxisol. On the Ultisols, soil acidity factors had very little effect on leaf composition. Yield increased with increasing soil $\mathrm{pH}$, decreasing exchangeable $\mathrm{Al}$ content and decreasing exchangeable $\mathrm{Al}$ /base ratio. When all the soils, except Coto, were grouped together, the ratio of exchangeable $\mathrm{Al}$ to exchangeable bases explained $83 \%$ of the variation, the percent $\mathrm{Al}$ saturation $79 \%$, and $\mathrm{pH}$ only $66 \%$. Highest yields were obtained when $\mathrm{pH}$ was above 5 , percent Al less than $20 \%$ and the $\mathrm{Al}$ exchangeable bases ratio less than .2. The lack of response in the Oxisol seems to be related to a reduced $\mathrm{Al}$ activity resulting from a high $\mathrm{Mn}$ concentration in the soil solution. Apparently sweet potato is very tolerant to high $\mathrm{Mn}$ concentrations in the soil solution.
\end{abstract}

\section{INTRODUCTION}

Sweet potato (Ipomoea batatas (L.) Lam) is a staple in the diet of millions throughout the humid tropics. Knowledge concerning lime requirements of sweet potato in tropical areas is both fragmentary and often contradictory (13). Bonnet et al. (7) found that sweet potato responded to liming on two red acid soils (Ultisols) of Puerto Rico. However, Camargo et al. (9) in Brazil found no response of sweet potatoes to liming on sandy acid soils. Lugo et al. (10) reported a yield increase of $15 \%$ due to liming Corozal soil, an Aquic Tropudults of Puerto Rico. Nye and Greenland (12) reported that sweet potato yields were increased by liming in only two of a series of very acid soils in Uganda. Pérez-Escolar (14) found no response of sweet potato to liming on two Ultisols and one Oxisol in Puerto Rico. Steinbauer and Beattie (15) using lime and calcium chloride as liming materials concluded that sweet potato yields were highest on slightly to moderately acid soil and may decrease if soil is

${ }^{1}$ Manuscript submitted to Editorial Board May 22, 1978.

${ }^{2}$ This paper covers work carried out cooperatively between the Science and Education Administration (formerly ARS), Agricultural Research, USDA, and the Agricultural Experiment Station, College of Agricultural Sciences, Mayagüez Campus, University of Puerto Rico.

${ }^{3}$ Soil Scientists, SEA, AR, USDA, Assistant and Associate Agronomists, Agricultural Experiment Station, College of Agricultural Sciences, Mayagüez Campus, University of Puerto Rico and Agricultural Technician, Science and Education Administration, USDA, respectively. 
TABLE 1.-Characteristics of the soils at the different experimental sites

\begin{tabular}{|c|c|c|c|c|c|c|c|}
\hline \multirow[b]{2}{*}{ Soil type } & \multirow[b]{2}{*}{ Classification } & \multirow[b]{2}{*}{ Origin } & \multirow[b]{2}{*}{$\begin{array}{l}\text { Predominating } \\
\text { clay mineral }\end{array}$} & \multicolumn{2}{|c|}{ Cation Exch Capacity ${ }^{1}$} & \multirow{2}{*}{$\begin{array}{l}\text { Ex- } \\
\text { change } \\
\text { able } \\
\text { Al }\end{array}$} & \multirow[b]{2}{*}{$\mathrm{pH}$} \\
\hline & & & & $\begin{array}{l}\text { Sum of exch } \\
\text { cations }\end{array}$ & $\begin{array}{l}\mathrm{NH}_{4} \mathrm{OAc} \\
\mathrm{pH} 7.00\end{array}$ & & \\
\hline & & & & \multicolumn{2}{|c|}{$\mathrm{Me} / 100 \mathrm{~g}$} & \multicolumn{2}{|c|}{$\mathrm{Me} / 100 \mathrm{~g}$} \\
\hline Corozal clay & Aquic Tropudults & Tuffaceous material & Kaolin & 12.9 & 19 & 4.7 & 4.6 \\
\hline Corozal clay subsoil & Do. & Do. & Do. & 11.3 & 16 & 5.1 & 4.6 \\
\hline Humatas clay & Typic Tropohumults & Volcanic tuff & Do. & 10.6 & 15 & 4.9 & 4.3 \\
\hline Coto sandy clay & Tropeptic Haplorthox & $\begin{array}{l}\text { Limestone quartzitic } \\
\text { sand deposits }\end{array}$ & Do. & 3.7 & 5 & .9 & 4.5 \\
\hline
\end{tabular}

'Sum of exchange cations includes $\mathrm{Ca}, \mathrm{Mg}, \mathrm{K}$ and $\mathrm{Al}$. Exchangeable bases ( $\mathrm{Ca}, \mathrm{Mg}, \mathrm{K}$ ) were extracted with normal ammonium acetate, 
neutral or alkaline. Watts and Cooper (16) found that, on a soil whose $\mathrm{pH}$ was lowered with $\mathrm{H}_{2} \mathrm{SO}_{4}$, sweet potato yields were highest at $\mathrm{pH} 6.0$ to 6.5 , and lowest at $\mathrm{pH} 6.5$ to 7.0 .

The present study determined the relationship between the various soil acidity factors and yields and foliar composition of sweet potatoes in four field experiments on three Ultisols and one Oxisol.

\section{MATERIALS AND METHODS}

The experiments were carried out on 30 plots on Corozal clay soil (Aquic Tropudults), 30 on Corozal subsoil (Aquic Tropudults), 60 on

TABLE 2.-Effect of soil acidity factors on yield and foliar composition of sweet potato

\begin{tabular}{|c|c|c|c|c|c|c|c|c|c|c|}
\hline \multicolumn{3}{|c|}{ Soil factors } & \multicolumn{2}{|c|}{ Yield } & \multicolumn{6}{|c|}{ Leaf composition } \\
\hline $\mathrm{pH}$ & Al sat. & $\begin{array}{l}\text { Ratio } \\
\text { Al/bases }\end{array}$ & Actual & Relative & $\mathrm{N}$ & $\mathrm{P}$ & K & $\mathrm{Ca}$ & $\mathrm{Mg}$ & $\mathrm{Mn}$ \\
\hline & $\%$ & & t/ha & $\%$ & $\%$ & $\%$ & $\%$ & $\%$ & $\%$ & $p / m$ \\
\hline \multicolumn{11}{|c|}{ Corozal clay soil } \\
\hline 5.60 & 3 & .03 & 13.8 & 100 & 5.03 & .69 & 3.00 & .88 & .33 & - \\
\hline 5.00 & 12 & .13 & 13.1 & 95 & 5.13 & .75 & 3.59 & .77 & .27 & - \\
\hline 4.80 & 26 & .36 & 12.3 & 89 & 5.02 & .58 & 2.64 & .88 & .34 & - \\
\hline 4.60 & 33 & .49 & 9.1 & 66 & 4.93 & .62 & 3.00 & .63 & .34 & - \\
\hline 4.50 & 43 & .78 & 8.9 & 64 & 5.18 & .63 & 2.58 & .82 & .32 & - \\
\hline 4.40 & 50 & .97 & 6.8 & 49 & 4.91 & .62 & 2.73 & .79 & .35 & - \\
\hline 4.20 & 66 & 2.03 & 3.1 & 22 & 4.42 & .55 & 2.27 & .79 & .34 & - \\
\hline \multicolumn{11}{|c|}{ Corozal clay subsoil } \\
\hline 5.50 & 5 & .06 & 11.5 & 96 & 5.02 & .69 & 3.00 & .80 & .38 & - \\
\hline 4.95 & 15 & .17 & 12.0 & 100 & 5.06 & .68 & 3.20 & .71 & .40 & - \\
\hline 4.70 & 25 & .35 & 11.9 & 99 & 5.01 & .65 & 2.99 & .72 & .38 & - \\
\hline 4.60 & 35 & .55 & 12.0 & 100 & 4.90 & .64 & 2.85 & .68 & .36 & - \\
\hline 4.50 & 43 & .69 & 11.2 & 93 & 4.90 & .69 & 2.86 & .72 & .38 & - \\
\hline 4.35 & 56 & 1.27 & 8.2 & 68 & 4.80 & .63 & 2.91 & .70 & .30 & - \\
\hline 4.15 & 63 & 1.70 & 6.8 & 57 & 4.78 & .66 & 2.89 & .64 & .36 & - \\
\hline \multicolumn{11}{|c|}{ Humatas clay } \\
\hline 5.30 & 4 & .04 & 7.37 & 100 & 3.77 & .51 & 3.18 & .86 & .26 & - \\
\hline 4.85 & 14 & .17 & 5.97 & 81 & 4.04 & .51 & 3.01 & .78 & .28 & - \\
\hline 4.70 & 26 & .34 & 5.78 & 78 & 3.61 & .48 & 2.82 & .69 & .28 & - \\
\hline 4.45 & 35 & .53 & 6.18 & 84 & 3.95 & .48 & 3.00 & .64 & .30 & - \\
\hline 4.30 & 46 & .85 & 5.23 & 71 & 3.98 & .51 & 2.98 & .69 & .32 & - \\
\hline 4.10 & 56 & 1.29 & 3.40 & 46 & 3.83 & .53 & 2.82 & .72 & .31 & - \\
\hline 3.80 & 67 & 2.06 & 1.37 & 18 & 3.71 & .49 & 2.54 & .59 & .27 & - \\
\hline \multicolumn{11}{|c|}{ Coto sandy clay } \\
\hline 5.3 & 5 & .03 & 16.1 & 90 & 4.53 & .54 & 2.89 & 1.27 & .30 & 237 \\
\hline 4.7 & 15 & .19 & 16.5 & 92 & 4.61 & .54 & 3.13 & 1.16 & .32 & 286 \\
\hline 4.5 & 25 & .33 & 17.0 & 95 & 4.59 & .50 & 3.19 & 1.15 & .36 & 280 \\
\hline 4.3 & 35 & .56 & 17.9 & 100 & 4.88 & .54 & 3.15 & 1.20 & .30 & 395 \\
\hline
\end{tabular}


Humatas clay (Typic Tropohumults) and 40 on Coto sandy clay (Tropeptic Haplorthox). All plots were $4 \mathrm{~m}^{2}$ and were surrounded by ditches. The experimental design was a completely randomized series of plots with different concentrations of $\mathrm{Al}, \mathrm{Mn}, \mathrm{Ca}$ and $\mathrm{Mg}$ resulting from different lime rates.

The soil in each plot was sampled by taking 10 borings at $0-15 \mathrm{~cm}$ depth. The samples were air dried and passed through a 10-mesh screen.

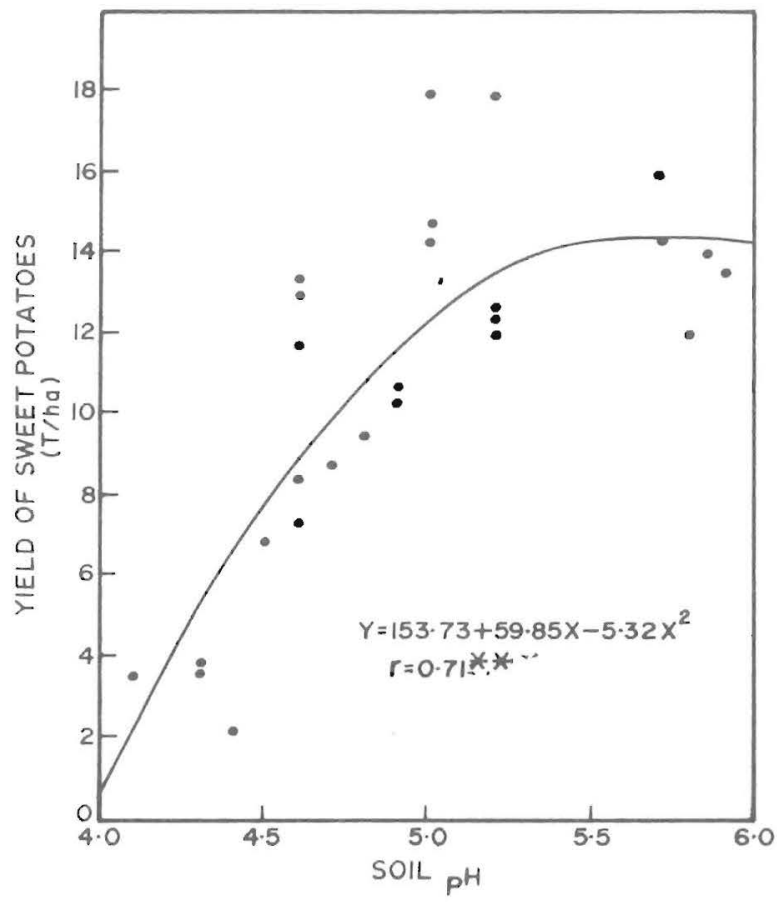

FIG. 1.-Effect of $\mathrm{pH}$ on yield of sweet potato grown on a Corozal clay soil.

Exchangeable bases $(\mathrm{Ca}+\mathrm{Mg}+\mathrm{K})$ were extracted with normal ammonium acetate $\mathrm{pH}$ 7.0, and $\mathrm{Ca}$ and $\mathrm{Mg}$ were determined by the Versenate titration method (8). Potassium was determined by flame photometry. Exchangeable $\mathrm{Al}$ was extracted with normal $\mathrm{KCl}$ and determined by the double titration method (11). Al saturation percentage was determined by dividing the exchangeable $\mathrm{Al}$ by the sum of exchangeable $\mathrm{Ca}+\mathrm{Mg}$ $+\mathrm{K}+\mathrm{Al}$. Soil reaction was measured with a glass electrode, using a saturated paste.

Stem cuttings of the white-fleshed Yoya variety were planted $45 \mathrm{~cm}$ apart on elevated beds $90 \mathrm{~cm}$ apart. The Corozal clay soil and Corozal clay subsoil plots were planted in October 1971 and harvested in March 
1972. The Coto sandy clay plots were planted in September 1971 and harvested in March 1972. The Humatas clay plots were planted in August 1971 and harvested in February 1972.

In all experiments, rainfall was supplemented by overhead irrigations during dry spells. All plots received $1,120 \mathrm{~kg} / \mathrm{ha}$ of a $15-5-10$ fertilizer and were kept free of weeds by periodical hoeing.

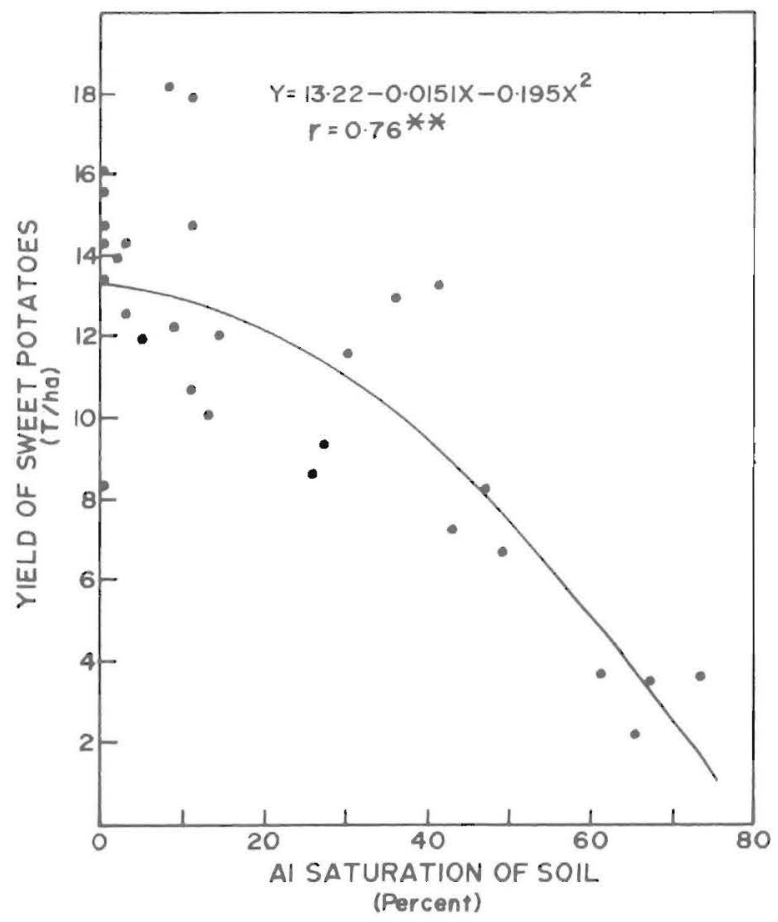

FIG. 2.-Effect of percent aluminum saturation on yield of sweet potato grown on a Corozal clay soil.

Leaf samples were taken from all plots 4 mo after planting and were analyzed for $\mathrm{Ca}$ and $\mathrm{Mg}$ by the Versenate method, $\mathrm{K}$ by flame photometry, $\mathrm{Mn}$ by oxidation with potassium periodate, $\mathrm{P}$ colorimetrically, and $\mathrm{N}$ by the Kjeldahl method.

Crop response to soil acidity factors was determined by correlating through regression analyses these factors with tuber yield and foliar composition.

\section{RESULTS AND DISCUSSION}

The main characteristics of the soils are shown in table 1. 
COROZAL CLAY SOIL (AQUIC TROPUDULTS)

Table 2 shows that sweet potato yields were maximum at an average $\mathrm{pH}$ of 5.6 and $3 \% \mathrm{Al}$ saturation. Below $\mathrm{pH}$ of 4.5 and $43 \% \mathrm{Al}$ saturation, yields decreased rapidly.

These data also show that leaf composition was not greatly affected by soil acidity factors, unlike soybeans (6), corn (4) and green beans (3). The

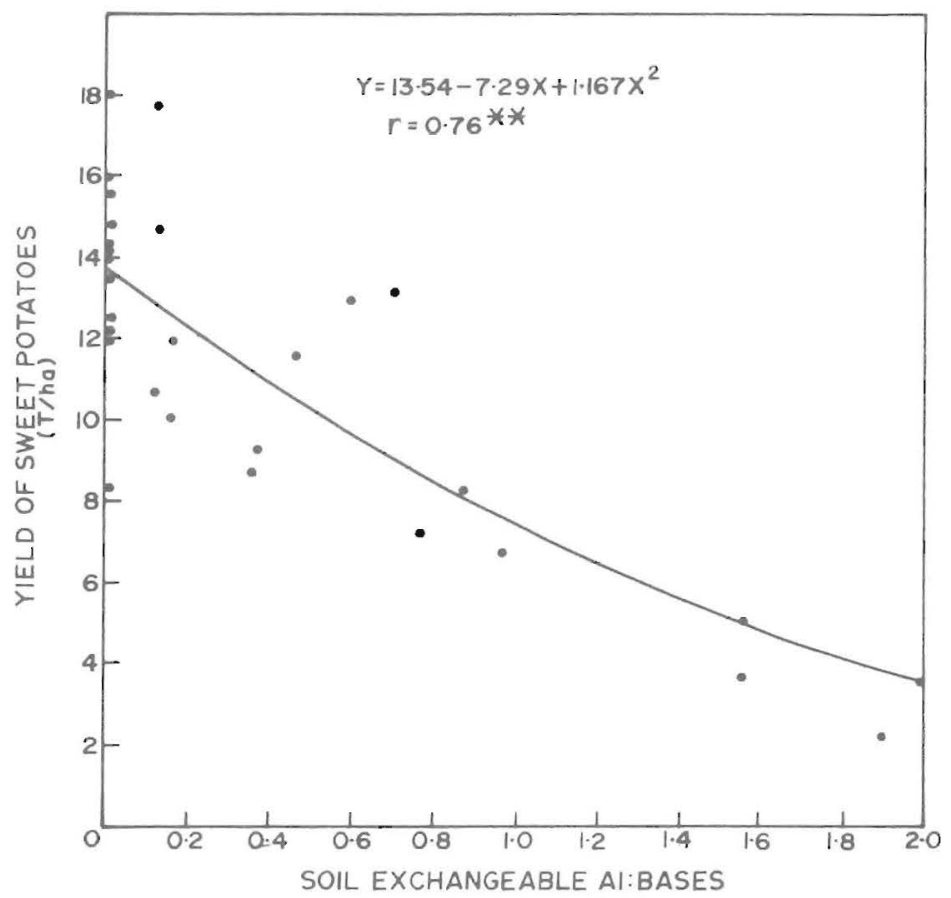

Fig. 3.-Effect of the ratio of exchangeable aluminum to exchangeable bases on the yield of sweet potato grown on a Corozal clay soil.

fact that Ca uptake by sweet potato was not significantly affected possibly explains the higher tolerance of sweet potatoes to soil acidity.

Figure 1 shows that sweet potato yields increased with $\mathrm{pH}$ from 4.0 to 5.3 and then levelled off. This response corresponds with the precipitation of active Al.

Figure 2 shows the relationship between percent $\mathrm{Al}$ saturation of the soil and sweet potato yields. Sweet potato yields were highest when Al saturation of the soil was less than $20 \%$ and lowest (20\% of maximum) at about $70 \%$ saturation. This contrasts with essentially no yields of tobacco (2) at $\mathrm{Al}$ saturation levels of about $50 \%$. 
Figure 3 shows that yields of sweet potatoes were maximum when the ratio of exchangeable $\mathrm{Al} /$ bases was less than 0.2 , corresponding to about $25 \% \mathrm{Al}$ saturation.

Sweet potatoes on this soil proved to be more tolerant than tobacco (2), green beans (3), corn (4), or soybeans (6) to high soil acidity.

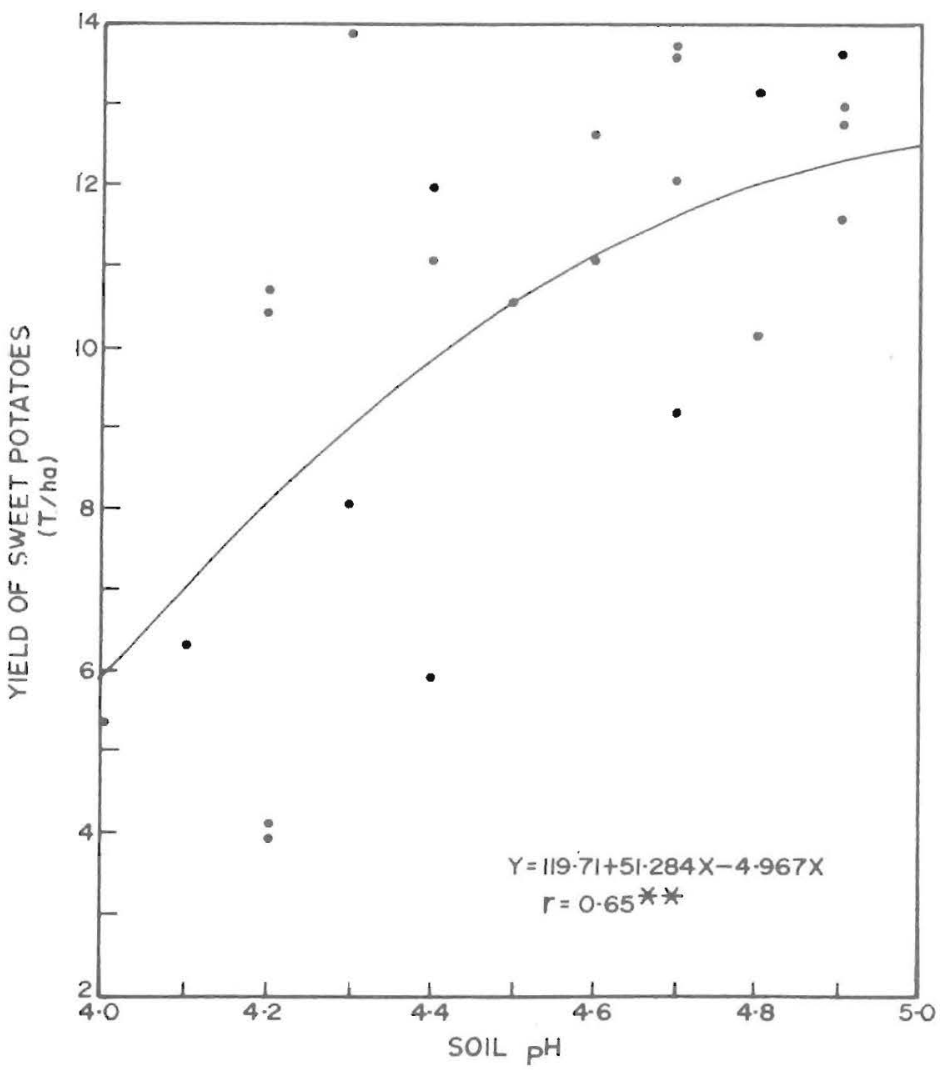

FIG. 4.-Effect of $\mathrm{pH}$ on yield of sweet potato grown on a Corozal clay subsoil.

COROZAL CLAY SUBSOIL (AQUIC TROPUDULTS)

Table 2 shows that at the highest lime levels yields were about $80 \%$ of those obtained on the Corozal soil and decreased as acidity increased much less than those for the Corozal soil. Even at $\mathrm{pH} 4.5$ and $43 \% \mathrm{Al}$ saturation, sweet potato yields were $93 \%$ of maximum compared with only $64 \%$ in the Corozal soil at this acidity level. Also at the lowest $\mathrm{pH}$ level (4.2) and highest Al saturation (63\%), yields were twice as high as those for the Corozal soil. 
Since the percent $\mathrm{Al}$ saturation, $\mathrm{pH}$ and $\mathrm{Al} /$ base ratio levels are similar in both soils, this strikingly lower response in the subsoil to liming apparently can be explained only on the basis of less active forms of Al.

There was no effect of soil acidity on foliar composition.

Figure 4 shows that in this subsoil yields were maximum at about $\mathrm{pH}$ 4.8 , at which there was some active $\mathrm{Al}$. This again suggests that this soil may have a less active $\mathrm{Al}$ form.

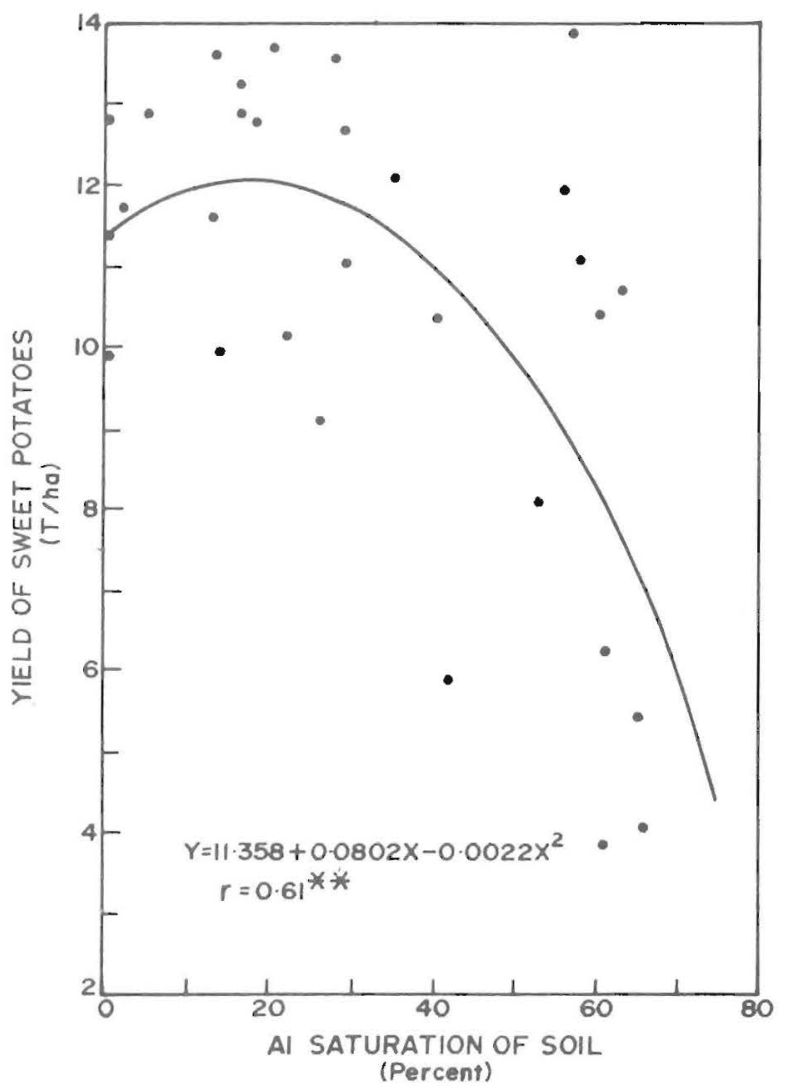

FIG. 5.-Effect of percent aluminum saturation on the yield of sweet potato grown on Corozal clay subsoil.

Figure 5 indicates that on this soil yields were maximum at about $20 \%$ $\mathrm{Al}$ saturation. There is a high degree of dispersion reflected in a low correlation coefficient value $(r=0.61)$.

Figure 6 shows the effect of exchangeable $\mathrm{Al} /$ base ratio on sweet potato yields. Like other soil acidity factors, there was a high degree of dispersion and a low correlation coefficient $(r=0.63)$. Yields were highest at about 
a ratio of $0.2-0.3$, corresponding to about $20 \% \mathrm{Al}$ saturation. At this level, the yields varied from 10 to $13.6 \mathrm{t} / \mathrm{ha}$.

In general, sweet potato is much more tolerant to soil acidity factors on this soil than were tobacco (2), corn (4), green beans (5), or soybeans (6).

\section{HUMATAS CLAY (TYPIC TROPOHUMULTS)}

Table 2 shows that maximum sweet potato yields were only about $50 \%$ of those obtained on Corozal clay soil and $64 \%$ of those on Corozal clay subsoil. These low yields were probably due to planting during a season during which yields of sweet potatoes are generally lower.

Sweet potatoes on this soil responded to liming in a similar manner to that on the Corozal clay soil. Yields were maximum at $\mathrm{pH} 5.3$, but were about $80 \%$ of maximum at $\mathrm{pH}$ 's of 4.50 and $35 \% \mathrm{Al}$ saturation.

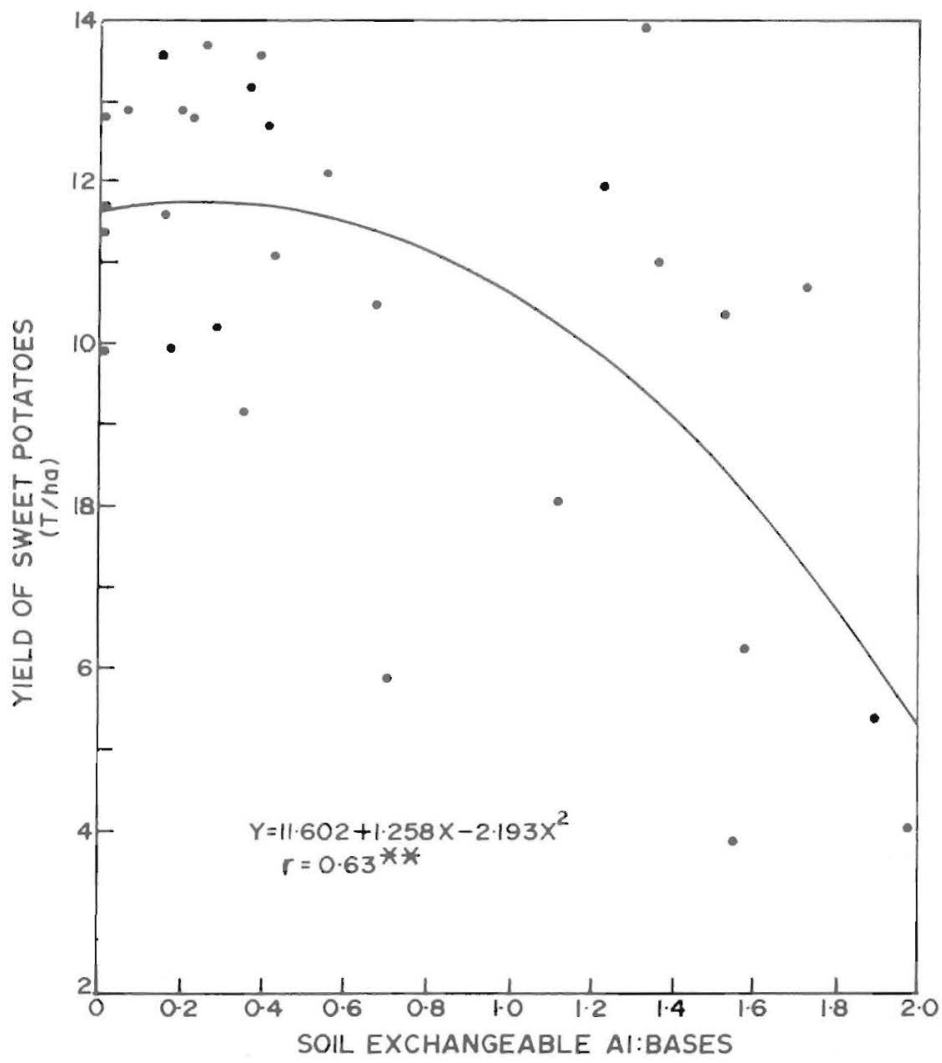

FIG. 6.-Effect of the ratio of exchangeable aluminum to exchangeable bases on yield of sweet potato grown on Corozal clay subsoil. 
Soil acidity factors did not affect leaf composition except Ca content of leaves correlated with yield (fig. 7), with an $r$ value of only 0.57 .

Figure 8 shows a large yield response of sweet potatoes to $\mathrm{pH}$ levels in this soil. Yields increased rapidly with increasing $\mathrm{pH}$ up to about 5.0, with no further response at higher $\mathrm{pH}$ values.

Figure 9 shows that sweet potatoes responded sharply in yield to decreased $\mathrm{Al}$ saturation up to about 20\%. The sweet potatoes were more

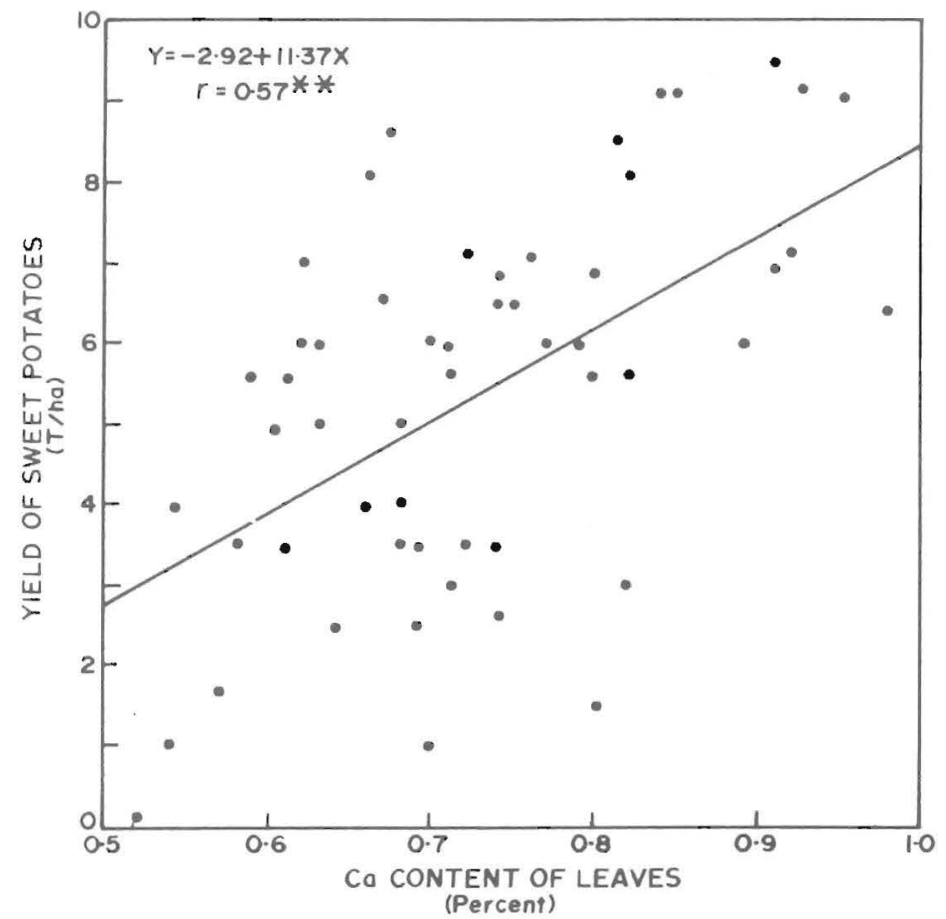

FIG. 7.-Relationship between the calcium content of the leaves and the yield of sweet potato grown on Humatas clay soil.

tolerant to high soil acidity than were sugarcane (1), tobacco (2), or soybeans (6) on Humatas clay soil.

Figure 10 shows a negative significant correlation between the ratio of exchangeable $\mathrm{Al} /$ bases and sweet potato yields on this soil. Yields were maximum when the ratio was less than 0.2 corresponding to less than $20 \% \mathrm{Al}$ saturation in the soil. When this ratio increased to about 1.8, yields decreased to about $2 \mathrm{t} / \mathrm{ha}$.

\section{COTO SANDY CLAY (TROPEPTIC HAPLORTHOX)}

This soil, the only Oxisol studied, is much higher in both exchangeable and easily reducible $\mathrm{Mn}$ than the Ultisols, but has a lower $\mathrm{Al}$ content at 
any given $\mathrm{pH}$ than the other soils. The lack of response in the soil seems to be related to a reduced $\mathrm{Al}$ activity in the soil solution as a result of a high $\mathrm{Mn}$ concentration. In addition, sweet potato seems to be very tolerant to high concentrations of soluble $\mathrm{Mn}$ in the soil solution.

The data in table 2 show that sweet potato yields obtained on Coto sandy clay were higher than on any of the other soils, and that there was no significant effect of liming on yields.

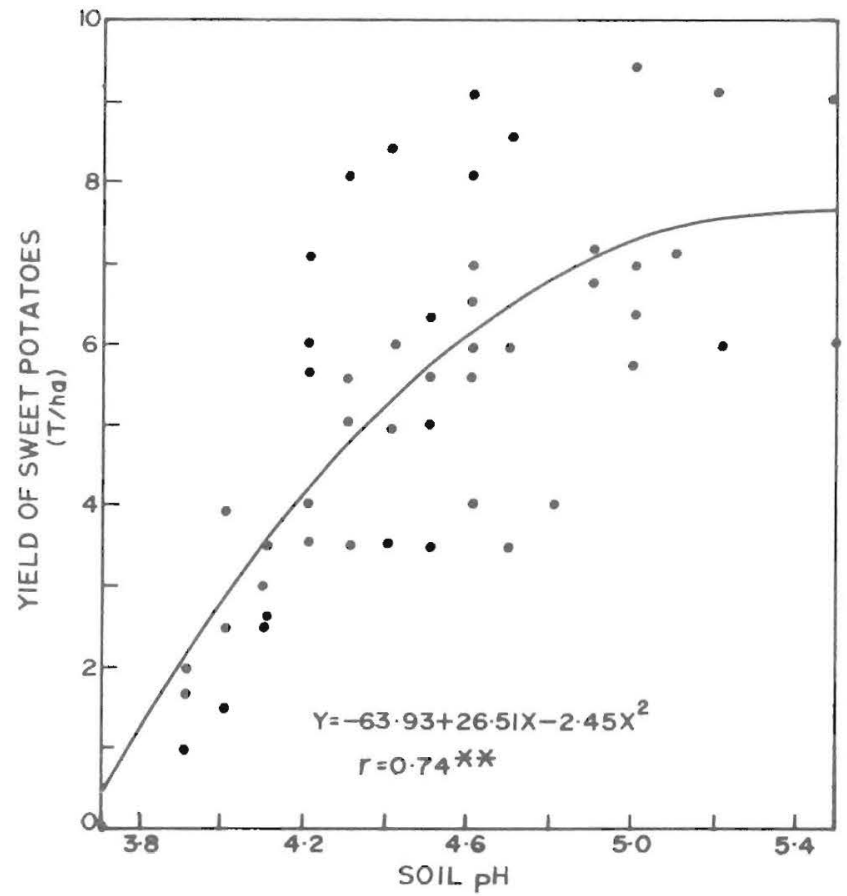

FIG. 8.-Effect of $\mathrm{pH}$ on the yield of sweet potato grown on Humatas clay.

Leaf composition was not significantly affected by variations in the various soil acidity factors, although $\mathrm{Mn}$ content increased as $\mathrm{pH}$ decreased.

\section{ALL SOILS COMBINED ${ }^{4}$}

There were close relationships between sweet potato yields and soil acidity factors when data for all soils were combined.

Figure 11 shows that, for all soils combined, yields were maximum at about $\mathrm{pH} 5.0$ and lowest at about $\mathrm{pH}$ 4.0. This figure also shows that

${ }^{4}$ Data for Coto soil was not included in the statistical analysis. It was plotted to illustrate the lack of response. 
yields increased sharply from about 20 to $100 \%$ of maximum as $\mathrm{pH}$ increased from 4.0 to 5.0. Each soil had a somewhat different yield response pattern, with the sharpest response on the Humatas soil, less response on Corozal subsoil (response only from pH 4.1 to 4.5), and no response on Coto sandy clay.

Figure 12 shows that sweet potato responded sharply to variations in

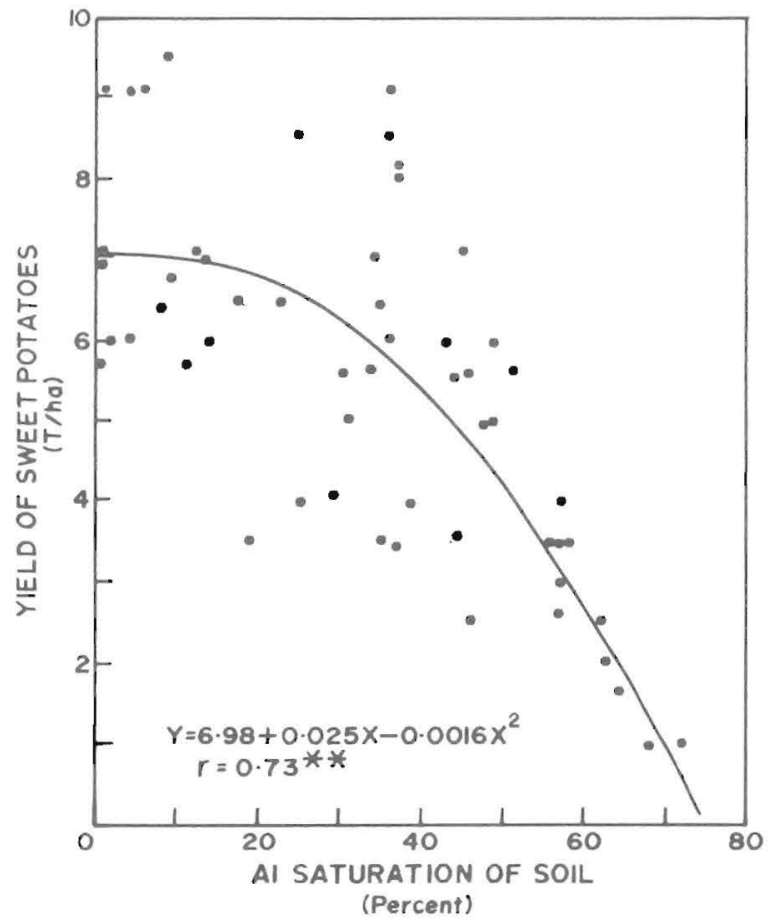

FIG. 9.-Effect of percent aluminum saturation on the yield of sweet potato grown on Humatas clay.

the percent $\mathrm{Al}$ saturation on the Ultisols but not on Oxisols (Coto sandy clay was the only Oxisol studied). Yields for all soils combined increased from about $20 \%$ of maximum at Al saturation of about $60 \%$ to about $100 \%$ at Al saturation of about $20 \%$ or less. Abruña et al. (5) found very weak response of corn to percent $\mathrm{Al}$ saturation on three Oxisols from Puerto Rico, but a strong response on Ultisols.

Sweet potatoes responded most sharply to Al content on Humatas soil and similarly on Corozal clay. The response on Corozal clay subsoil was considerably less.

Figure 13 shows, that for all soils combined (except Coto) yields of sweet potatoes correlated with the ratio of exchangeable Al to exchange- 


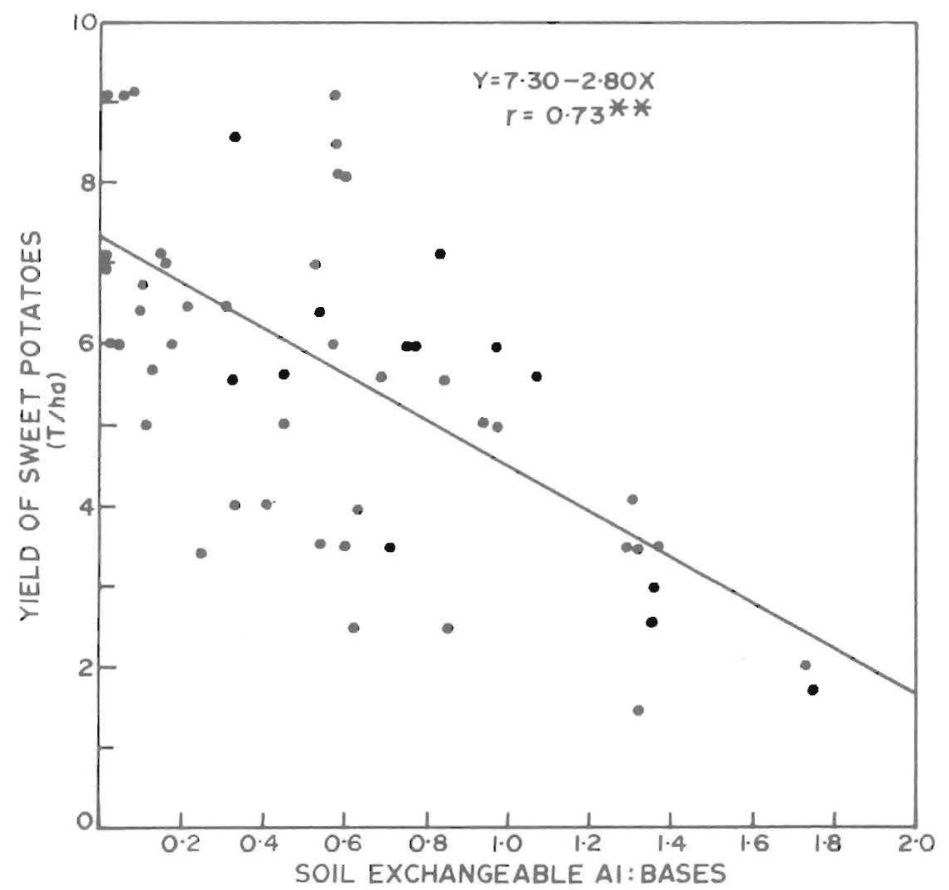

FIG. 10.-Effect of the ratio of exchangeable aluminum to exchangeable bases on yield of sweet potato grown on a Humatas clay soil. 


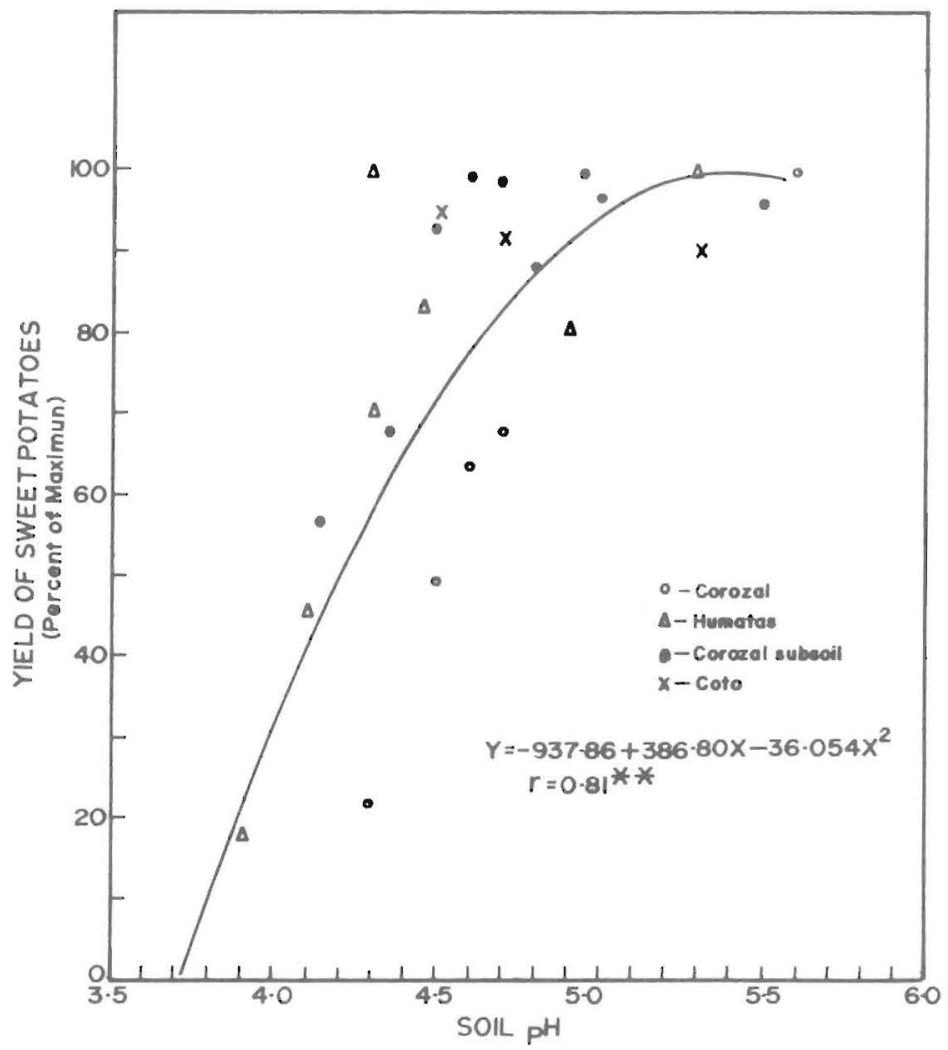

FIG. 11.-Effect of soil $\mathrm{pH}$ on relative yield of sweet potato grown on 3 Ultisols and 1 Oxisol. 


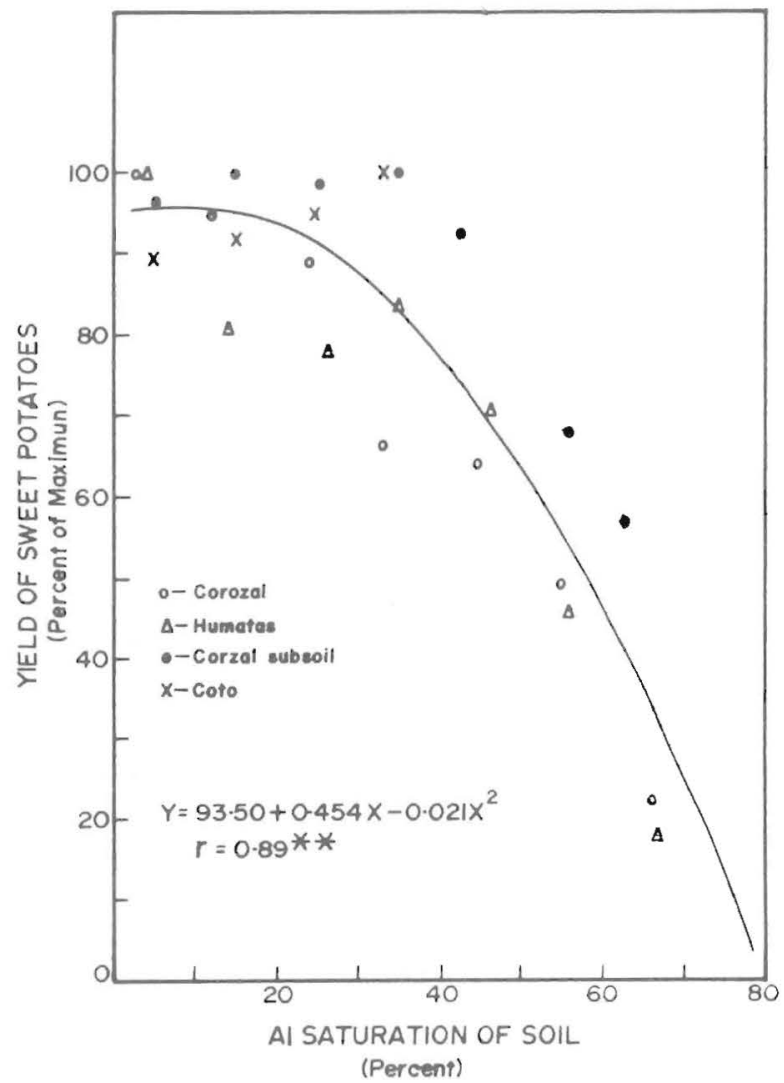

FIG. 12.-Effect of percent aluminum saturation on relative yield of sweet potato grown on 3 Ultisols and 1 Oxisol. 


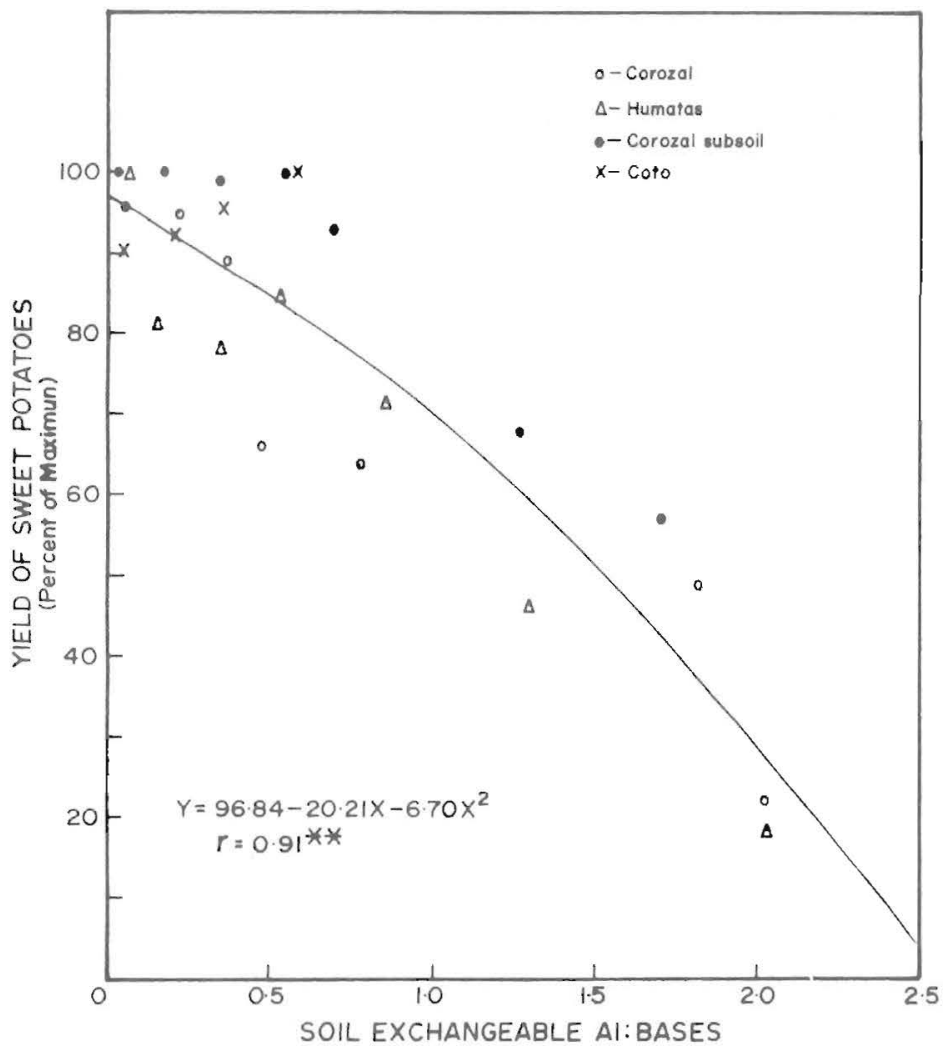

FIG. 13.-Effect of the ratio of exchangeable aluminum to exchangeable bases on the relative yield of sweet potato grown on 3 Ultisols and 1 Oxisol. 
able bases. Also, the Humatas and Corozal clay soil showed the strongest response followed by the Corozal subsoil, with no response in Coto sandy clay.

In general, for all soils combined (except Coto) we obtained the highest correlation between the ratio of exchangeable Al to exchangeable bases and sweet potato yields-the equation explained $83 \%$ of the variation. Percent Al saturation correlation explained $79 \%$ of the variations, and $\mathrm{pH}$ only $66 \%$.

\section{RESUMEN}

El efecto de los factores de acidez de cuatro suelos (tres Ultisoles y un Oxisol) en el rendimiento y composición foliar de la batata se estudió en la variedad Yoya.

La batata respondió señaladamente al encalado y el rendimiento se correlacionó significativamente con los distintos factores de acidez resultantes de incrementos en el encalado en los tres Ultisoles, pero no en el Oxisol, donde no hubo respuesta.

Las respuestas más pronunciadas se lograron en los suelos Corozal arcilloso y Humatas arcilloso en donde el rendimiento aumentó consistentemente hasta un $\mathrm{pH}$ de aproximadamente 5.0. Se lograron los mayores rendimientos cuando la saturación del complejo coloidal con aluminio fue de $20 \%$ o menos, o cuando la razón de aluminio cambiable a bases cambiables fue inferior a 0.2 .

En el subsuelo del suelo Corozal arcilloso la respuesta al encado fue menor que la de los suelos Humatas y Corozal arcilloso.

La batata no respondió a las aplicaciones de cal en el suelo Coto a pesar de las variaciones notables en $\mathrm{pH}$ y la saturación del aluminio resultantes del encalado variable. En vista de que el Al cambiable es el factor determinante en la respuesta en el suelo Coto puede interpretarse como que la forma en que el aluminio ocurre en este suelo es mucho menos activa que en los demás.

En términos generales puede concluirse que la batata es bastante más tolerante a las concentraciones de aluminio en el suelo que el tabaco, el maiz, las habichuelas tiernas o las sojas.

La falta de respuesta en el suelo Coto parece deberse a una menor actividad del ion aluminio debido a la preponderancia del ion manganeso en la solución del suelo.

\section{LITERATURE CITED}

1. Abruña-Rodríguez, F., and Vicente-Chandler, J., 1967. Sugarcane yields as related to acidity of a humid tropic Ultisol, Agr. J., 59: 330-31.

2. - Pearson, R. W., and Silva, S., 1970. Crop response to soil acidity factors in Ultisols and Oxisols, I. Tobacco, Soil Sci. Soc. Am. Proc. 34: 629-35.

3. - - Pérez-Escolar, R., Vicente-Chandler, J., Figarella, J., and Silva, S., 1974. Response of green beans to acidity factors in tropical soils, J. Agri. Univ. P.R., 58 (1): 44-58.

4. - - Pearson, R. W., and Silva, S., 1974. Response of corn to acidity factors in eight tropical soils, J. Agri. Univ. P.R., 58 (1): 59-77.

5. — - Pearson, R. W., and Pérez-Escolar, R., 1975. Lime response of corn and beans in typical Ultisols and Oxisols of Puerto Rico. Soil Management in Tropical America, published by Univ. Consortium of Soils of the Tropics, N. C. State Univ.

6. - Rodriguez, J., Badillo, J., Silva, S., and Vicente-Chandler, J., 1978. Crop response to soil acidity factors in Ultisols and Oxisols in Puerto Rico, III. Soybean, J. Agri. Univ. P.R., 62 (1): 90-112.

7. Bonnet, J. A., Tirado-Sulsona, P., and Abruña, F., 1947. Effect of lime-phosphorus and green manure on sweetpotato and corn grown in acid soils, J. Agri. Univ. P.R., 31 (4): 303-21.

8. Cheng, K. L. and Bray, R. H., 1951. Determination of calcium and magnesium in soil and plant material, Soil Sci. 72: 449-58. 
9. Camargo, P., Freires, E. S., and Venturi, W. R., 1962. Efeito da calagem e de diversas adubaçōes na batata-doce e no cara em solos de baixa fertilidade derivados do arenito Batucatu, Bragantia 21: 143-61.

10. Lugo-López, M. A., Hernández-Medina, E., and Acevedo, G., Response of some tropical soils and crops of Puerto Rico to applications of lime, Agri. Exp. Sta. Univ. P.R., Tech. Pap. No. 28, 1959.

11. McLean, E. O., 1965. Aluminum. Methods of Soil Analysis, Am. Soc. Agron. Agron. Series \#9, 994-96.

12. Nye, P. H. and Greenland, D. J., 1960. The soils under shifting cultivation, Commonwealth Bur. Soils Tech. Comm. 51, 1956, pp.

13. Pearson, R. W., 1975. Soil acidity and liming in the humid tropics, Cornell Int. Agri. Bull. 30, Cornell Univ., Ithaca, N.Y.

14. Pérez-Escolar, R., 1977. Effect of soil pH and related acidity factors on yield of sweetpotatoes and soybeans grown on typical soils of the humid tropics, J. Agri. Univ. P.R., 61 (1): 82-9.

15. Steinbauer, C. E. and Beattie, J. H., 1938. Influence of lime and calcium chloride applications on growth and yields of sweetpotatoes, Hort. Am. Soc. Proc., Hort. Sci. pp. $526-32$.

16. Watts, V. M. and Cooper, J. R., 1943. Influence of varied soil reactions on growth and yield of vegetable crops in Newtonia silt loam and Ruston fine sandy loam soils, Arkansas Agri. Exp. Stn., Bull. 433. 